\title{
INTERFERENCE IN LEARNING ENGLISH: GRAMMATICAL ERRORS IN ENGLISH ESSAY WRITING AMONG SEVENTH GRADERS OF MTS DARUL ULUM, SUKOSEWU, BOJONEGORO, EAST JAVA
}

\author{
M. Ali Ghufron \\ Department of English Teaching \\ Faculty of Letters and Arts Education IKIP PGRI Bojonegoro \\ alghufron.87@gmail.com
}

\begin{abstract}
The purpose of this research was to present an analysis of interference effect, a factor that plays an important role in inhibiting the acquisition of English among seventh grade students of MTs Darul Ulum, Sukosewu, Bojonegoro, East Java. The data substantiating the discussion throughout this article came from an empirical study of errors in essays written by seventh grade students of MTs Darul Ulum in the academic year of 2015/2016. The participants were all students in 7A class consisting of 30 students. The participants were chosen by cluster random sampling. The findings of the study show that the learners are still having difficulty in using correct English grammar in their writings. The three most frequent errors are: 1) the use of articles, 2) subject-verb agreement, and 3) copula 'be'.
\end{abstract}

Keywords: Interference, Grammatical errors.

\section{A. Introduction}

The strong version of Contrastive Analysis (CA) claims that the differences between first language (L1) and second language (L2) structures will result in negative transfer due to the transfer of old habits into new ones. However, this version of $\mathrm{CA}$ is only predictive in nature and is not always true. Errors made by learners give us better insights into the process of language learning. Due to this, errors are now regarded as a very important tool for diagnostic purposes in language teaching, at least in the English as a Foreign Language (EFL) context.

This article analyze the influence of the Indonesian language on learning English in a number of seventh grade students of MTs Darul Ulum Sukosewu Bojonegoro. Studies carried out by Nooreiny et al. (2003) and Shaari (1987) found that despite going through the same curriculum, the level of English proficiency in rural schools is much lower than the level in the urban schools. Shaari (1987), in particular, found that the major difficulty faced by many of the students is learning the English grammar. This difficulty may also be attributed to the environment in which language acquisition occurs. In the case of Indonesian students, most of them tend to use the Indonesian language when interacting with their family 
members and friends in their home environment as well as in school. They also use their mother tongue to converse with their non-Indonesian peers who are fluent in the Indonesian language too. Hence, they hardly use English outside the language classroom, resulting in weak performances in their writing, reading, speaking and listening skills. The problem is most obvious when it comes to examinations. It is always difficult to find students writing their essays with very few grammatical errors; specifically in the use of tenses and word order. When the problem is obvious, teachers or educators need to understand both the linguistic and nonlinguistic causes of the errors. Within the second language acquisition perspective, two ways of looking at these problems are through contrastive and error analyses. These two ways formed the bases for analysis in this study. This article presents one of the many contributions of contrastive and error analyses in understanding the phenomena of second language acquisition, especially in the acquisition of a global language, i.e. English, in an EFL context. The factors that set this article apart from others discussing related matters are the subjects, schools, and area selected.

\section{B. Research Method}

This research belongs to case study research. It was designed to uncover something of the complexity of language use in a particular sample of language learners and so it had an explicit descriptive purpose. It is aimed at investigating the L1 grammatical aspects that influence most in writing English.

The participants in this research are 30 students of the 7A class of MTs Darul Ulum Purwoasri Sukosewu in the academic year of 2015/2016. The participants were chosen by cluster random sampling from 2 classes (7A and 7B). At the initial stage of data collection, permission was sought from the class teachers involved to allow half an hour of the class' time for free writing activity. The students were given the liberty of selecting the topics but these have been found to evolve around "My best friend" and "My family".

Data were analysed following Norrish's (1992) approach to conducting Error Analysis. This includes sample collection, identifying errors, describing errors, explaining and evaluating errors. Contrastive analysis was used as part of the procedure to explain the occurrences of errors.

\section{Results and Discussion: Interference in Learning English}

It should be stated here that even though in principle, there were 60 essays, only half of them were analyzable - the other half were simply incomprehensible, hence could not be included in any categories of 
errors. This has been anticipated as given the area of study, and the social as well as academic backgrounds of the students, most students in the rural areas may have only attained the English language at the intermediate level of proficiency (Hazita 2006).

The length of the essays ranged from 50 to 100 words. Based on the kinds of errors observed, determiner, subject-verb agreement, and copula "be" are the three most problematic grammatical categories among the learners. The following sections discuss these three most frequent types of errors in the data.

\section{Determiner}

Celce-Murcia \& Larsen-Freeman (1999) describe 'determiner' as a special class of words that limits (or determines) the nouns that follow them. These words could be in the form of articles (the, $a(n)$ ), demonstratives (this, that, these, those), possessive determiners (my, your, his, her, its, our, their) and quantifiers (one, two, ten million). Structurally, a determiner precedes an adjective if there are adjectives in the noun phrase. In cases where no adjectives are present, they are positioned directly in front of a noun. Where the sentence "I put my books on the huge table." is concerned, two determiners can be detected. The first is 'my', a possessive determiner that precedes the noun 'books' while the second is 'the', a definite article that precedes the adjective 'huge'. In both cases, both 'my books' and 'the huge table' are noun phrases. Determiners of the English language are often restricted with respect to the number and or countability of the head nouns with which they can co-occur. These agreement features are important information about determiners and nouns that are unique to a language like the English language (CelceMurcia \& Larsen-Freeman 1999:83). Similar to determiners in English, determiners in the Indonesian language also form part of a noun phrase. Coined as 'kata penentu' (words that determine) in the Indonesian grammar (Abdullah Hassan 1993:54), the Indonesian equivalent to the English determiner, however, is often illustrated as, and only limited to, the words 'itu' (that) and 'ini' (this). These words, on the other hand, are described as 'kata penunjuk' (words that point). 
Table 1 Indonesian determiners and their English equivalents

\begin{tabular}{ll}
\hline \multicolumn{1}{c}{ Indonesian Structure } & \multicolumn{1}{c}{ English Structure } \\
\hline Orang laki-laki itu adalah paman saya & $\begin{array}{l}\text { The man is my uncle } \\
\text { Net }+ \text { Noun }\end{array}$ \\
Ayah saya seorang guru & $\frac{\text { My Father is a teacher }}{\text { Det }+ \text { Noun }}$ \\
\hline Noun + Det & $\frac{\text { That black trousers }}{\text { Celan hitam itu ...... }}$ \\
\hline Noun $+A d j+D e t+A d j+$ Noun
\end{tabular}

Despite the difference in the terms used, both Indonesian linguists agree that structurally, the words 'itu' and 'ini' have to be the final element in any Indonesian noun phrases. There should be modifiers after the head noun, the modifiers come between the head noun (on the left) and the kata penentu (on the right). Abdullah Hassan (1993:54) stresses that there must not be any other word after the kata penentu in the Indonesian noun phrase. Abdullah Hassan's description is true to a certain extent because he does not regard numerals as determiner.

In the following subsections instances of the incorrect usage of English determiners, particularly the omission and the wrong form of English determiners are illustrated.

\section{a. Omission of Determiner}

In the Indonesian grammar, the name of specific places or location like 'park', 'canteen', 'school', 'sea' need not be collocated with determiners, unless those places or locations have been specified earlier, or expressed deictically. Unlike the Indonesian language, the mentioning of those places or location in the English language, requires a determiner, in any cases. If the expressions are not expressed deictically, it will then be expressed either with a definite article, or an indefinite article. Thus, where this research is concerned, the students failed to insert the article 'the' and produced sentences shown in Table 2.

Table 2 The absence of 'the' for specific places or locations

\begin{tabular}{ll}
\hline \multicolumn{1}{c}{ Erroneous Form } & \multicolumn{1}{c}{ Correct Form } \\
\hline * often go to _ park with my family & I often go to the park with my family \\
Indonesia: Saya sering pergi ke taman & \\
bersama keluarga saya & \\
*My father works as an English teacher & My father works as an English teacher \\
at__ senior high school & at the senior high school. \\
Indonesia: Ayah saya bekerja sebagai & \\
seorang guru bahasa Inggris di SMA & \\
\hline
\end{tabular}


Indonesian grammar also does not require one to have any form of determiner in front of instruments like komputer, piano, internet. English grammar, however, requires the instruments mentioned above (computer, piano, internet) to be preceded by determiners and if neither a possessive determiner nor a demonstrative determiner is used, the use of either a definite article or an indefinite article is necessary. Thus, the ungrammatical sentences in Table 3 could be the result of interference of the Indonesian language structure on English:

Table 3 The absence of 'the' for instruments

\begin{tabular}{|c|c|}
\hline Erroneous Form & Correct Form \\
\hline $\begin{array}{l}\text { * got __ information from __ internet } \\
\text { Indonesia: Saya memperoleh informasi } \\
\text { itu dari internet }\end{array}$ & I got the information from the internet \\
\hline *My sister plays __ piano while I sing & My sister plays the piano while I sing \\
\hline \begin{tabular}{llll} 
Indonesia: & \multicolumn{2}{c}{ Saudara $(\mathrm{pr})$} & saya \\
memainkan & piano sementara & saya \\
menyanyi & & &
\end{tabular} & \\
\hline
\end{tabular}

\section{b. Wrong of Determiner}

Some determiners of the English language have to agree with the noun that comes after it - a property that does not apply to the Indonesian language. Thus, '*this balls' would be ungrammatical and the correct version would be 'these balls'. The example in Table 4 shows that the choice of determiner could be to the interference of the students' mother tongue.

Table 4 This + singular $\mathbf{N}$ and error

\begin{tabular}{l}
\hline \multicolumn{3}{c}{ Erroneous Form } & \multicolumn{1}{c}{ Correct Form } \\
*This three books are mine \\
$\begin{array}{l}\text { Indonesia: Ketiga buku ini adalah } \\
\text { punya saya }\end{array}$
\end{tabular}

Where possessive determiners are concerned, the forms of the Indonesian possessive determiners are similar to that of the noun in question. In mentioning "my ball", a person would express it in Indonesian as 'bola saya', with 'saya' in the similar form as the nominative case for 'I'. The forms of the Indonesian possessive determiners also remain the same when a proper name is used. For example, for 'Ali's ball', the grammatical Indonesian form would be 'bola Ali', with no inflections of any forms are required. Possessive determiners in the form of common nouns would also remain the way 
a common noun would look like and these common nouns also come after the head noun. In contrast, the forms of English possessive determiners are dissimilar to that of the noun in question. 'My ball', for example, would take a genitive form as it is a genitive case, while 'Ali' would have to be inflected to 'Ali's' to show that Ali is the possessor of the ball. Common nouns also have to be inflected to 'teacher's ball' to show that the ball belongs to the 'teacher' and all of them come before the head noun.

Table 5 Possessive determiner errors

\begin{tabular}{ll}
\hline \multicolumn{1}{c}{ Erroneous Form } & \multicolumn{1}{c}{ Correct Form } \\
\hline 'During I leisure time, I read books & During my leisure time, I read books \\
Indonesia: Disaat waktu luang, saya & \\
membaca buku. & My mother' name is Zulaeha \\
'My mother name is Zulaeha & \\
Indonesia: Nama ibu saya Zulaeha & His hobby is playing football \\
'He's hobby is playing football & \\
Indonesia: hobinya bermain sepak bola & \\
\hline
\end{tabular}

The above sub-sections clearly show that the use of Contrastive Analysis might just be the best tool to teach English determiners to Indonesiansians despite being an unpopular approach. This is because the above data show that the ESL learners are going through a diverging phenomenon of language learning, where a linguistic item in the students' mother tongue (or first language) can be expressed in different ways in the English language. It is hoped that the above data could help teachers to plan their English lessons and approach their teaching of English determiners in the manner that is most appropriate to their students.

\section{Subject-verb Agreement}

English grammar requires the subject and verb to agree in number: both must be singular, or both must be plural. Problems occur in the present tense because one must add an -s or -es at the end of the verb when the subjects or the entity performing the action is a singular third person: he, she, it, or words for which these pronouns could substitute. Other forms, do not take inflection.

Table 6 Agreement with numbers

\begin{tabular}{|c|c|c|c|}
\hline Person & Singular & & Plural \\
\hline $1^{\text {st }}$ & I like ice cream & & We like ice cream \\
\hline $2^{\text {nd }}$ & You like ice cream & & You like ice cream \\
\hline $3^{\text {rd }}$ & $\begin{array}{l}\mathrm{He} / \mathrm{she} / \mathrm{it} / \mathrm{andi} / \mathrm{the} \\
\text { likes ice cream }\end{array}$ & cat/ & They like ice cream \\
\hline
\end{tabular}


The rule tells learners to use the $3^{\text {rd }}$ person singular inflection (-s) if the subject is: Singular proper name (Adam, Amelia, UKM) Singular common noun (river, university, professor)
Mass noun (fruit, water, cereal)

Third person singular pronoun (he/she/it)

Elsewhere, no inflection is used in the present tense:

Table 7 Agreement and (non)inflections

\begin{tabular}{ll}
\hline \multicolumn{1}{c}{$\mathbf{3}^{\text {rd }}$ person singular infection } & \multicolumn{1}{c}{ No inflection } \\
\hline Andi walks to school & The students walk to school \\
The bus stops here & Those buses stop elsewhere \\
This cake tastes weird & (I, you) like fried rice \\
My mother likes fried rice & (we, you, they) like fried rice \\
\hline
\end{tabular}

\section{a. Agreement in Indonesian Grammar}

In Indonesian grammar, there is no such thing as a subject-verb agreement rule that requires inflections based on the number of the subject. The four basic sentence structures in Indonesian below show that the number or status of the subject does not affect the verb structures in the predicates and predicate sentences in Indonesian are constructed on either one of the four basic structures:

Table 8 Basic structure in Indonesian sentences

\begin{tabular}{|c|c|c|}
\hline Structure & Subject & Predicate \\
\hline \multirow[t]{3}{*}{1} & NP & NP \\
\hline & Saya/Dia/Mereka/Ali & Guru \\
\hline & I/He/They/Ali & Teacher \\
\hline \multirow[t]{3}{*}{2} & NP & VP \\
\hline & Saya/Dia/Mereka/Ali & Makan nasi \\
\hline & I/He/They/Ali & (eat/eats) rice \\
\hline \multirow[t]{3}{*}{3} & NP & AP \\
\hline & Saya/Dia/Mereka/Ali & Sangat rajin \\
\hline & I/He/They/Ali & Very diligent \\
\hline \multirow[t]{3}{*}{4} & NP & $\mathrm{PP}$ \\
\hline & Saya/Dia/Mereka/Ali & Di dapur \\
\hline & I/He/They/Ali & In the kitchen \\
\hline
\end{tabular}

Based on the above table, the suffixes that accompany the $3^{\text {rd }}$ person pronoun in English sentences is not of a concern in Indonesian sentences. Therefore for the first table (Table 6) that outlines the rule of English present tense third person singular suffix, -s or -es, the equivalent translation of the sentences in Indonesian would be shown 
in Table 9 below:

Table 9 English Structures with Indonesian equivalents

\begin{tabular}{cll}
\hline Person & \multicolumn{1}{c}{ Singular } & \multicolumn{1}{c}{ Plural } \\
\hline $1^{\text {st }}$ & I like ice cream & We like ice cream \\
& Indonesian: Saya suka es & Indonesia: kami suka es \\
& krim & krim \\
& You like ice cream & You like ice cream \\
& Indonesia: kamu suka es & Indonesia: kamu suka es \\
& krim & krim \\
& He/she/it/andi/the cat/ & They like ice cream \\
& likes ice cream $\quad$ Indonesia: mereka suka \\
& Indonesia: dia lk/dia es krim \\
& pr/andi/kucing/ suka es \\
& krim & \\
&
\end{tabular}

\section{b. Omission of the third person singular $-\mathrm{s}$}

The rule of a third person singular inflection in English causes confusion among Indonesian learners of English whose first language (L1) does not inflect a verb based on the status of the subject. Thus the third person singular marker in English is often omitted by the learners as shown in the sentences in Table 10:

Table 10 Omission of third person singular inflection in English by Indonesian learners

\begin{tabular}{|c|c|}
\hline Erroneous Form & \begin{tabular}{|c|} 
Correct Form \\
\end{tabular} \\
\hline $\begin{array}{l}\text { *M mother always cook rice averyday } \\
\text { Indonesian: Ibuku selalu memasak nasi } \\
\text { setiap hari }\end{array}$ & My mother always cooks rice everyday \\
\hline $\begin{array}{l}\text { "My father go to school at every } 7 \\
\text { o'clock in the morning } \\
\text { Indonesian: Aahku pergi ke sekolah } \\
\text { setiap pagi }\end{array}$ & $\begin{array}{l}\text { My father goes to school at every } 7 \\
\text { o'clock in the morning }\end{array}$ \\
\hline $\begin{array}{l}\text { * My sister often accompany me to } \\
\text { school } \\
\text { Indonesian: Saudara (pr) ku sering } \\
\text { menemaniku pergi ke sekolah }\end{array}$ & $\begin{array}{l}\text { My sister often accompanies me to } \\
\text { school }\end{array}$ \\
\hline $\begin{array}{l}\text { "He work as an English teacher at the } \\
\text { senior high school } \\
\text { Indonesian: Dia bekerja sebagai guru } \\
\text { bahasa Inggris di SMA }\end{array}$ & $\begin{array}{l}\text { He works as an English teacher at the } \\
\text { senior high school }\end{array}$ \\
\hline $\begin{array}{l}\text { Nhe always buy vegetables in the } \\
\text { market every morning } \\
\text { Indonesian: Dia selalu membeli sayuran } \\
\text { di pasar setiap pagi }\end{array}$ & $\begin{array}{l}\text { She always buys vegetables in the } \\
\text { market every morning }\end{array}$ \\
\hline "My uncle wash he's car in the morning & My uncle washes his car in the \\
\hline
\end{tabular}


Indonesian: Pamanku mencuci morning

mobilnya di pagi hari

"My aunt prepare food for breakfast

My aunt prepares food for breakfast

Indonesian: Bibiku mennyiapkan

makanan untuk sarapan

As there is a difference in the SVA rule in English and Indonesian, where verbs in Indonesian do not need to agree with the number or status of the subject, the omission of $-\mathrm{s}$ in sentences 1-7 above may be due to the interference from the learners' first language. The equivalence of the verbs in Indonesian in some of the sentences is underlined in the translated version below. The verbs are all in their base form.

\section{c. Wrong form of Subject-Verb}

However, there were also cases where verbs that occur with other subjects, especially with the first person pronoun I. This occurrence may also be due to the divergent principle of $1 \rightarrow$ many; where one form in the mother tongue has many equivalence in the target language learned. For instance, in the case of Indonesian learners learning the SVA rule in English, learners may have difficulty choosing the right SVA form for their sentences, thus producing sentences shown in Table 11 below.

the third person singular inflection is used in

Table 11 Wrong form of Agreement by Indonesian learners

\begin{tabular}{ll}
\hline \multicolumn{1}{c}{ Erroneous Form } & \multicolumn{1}{c}{ Correct Form } \\
\hline *I lives in Bojonegoro & I live in Bojonegoro \\
Indonesian: Saya tinggal di Bojonegoro & I live with my parents \\
*I lives with my parents & \\
Indonesian: Saya tinggal bersama & \\
dengan orang tua saya & I $\underline{\text { have a pet }}$ \\
"I has a pet & \\
$\begin{array}{l}\text { Indonesian: Saya mempunyai binatng } \\
\text { peliharaan }\end{array}$ & He $\underline{\text { works }}$ at the school \\
*He working at the school & \\
Indonesian: Dia bekerja di sekolah &
\end{tabular}

The examples in Table 11 involved the use of 'I', the first person singular as a subject of the verb. The verb that follows was wrongly produced because of the confusion of the form to choose in the target language when SVA does not exist in the learners' mother tongue.

\section{Copula "be"}

The word 'copula' originates from the Latin noun for a 'link or tie' that connects 
two different things. In linguistics, a copula is a word that is used to link the subject of a sentence with a predicate (a subject complement or an adverbial). Though it might not itself express any action or condition, it serves to equate (or associate) the subject with the predicate. The copula 'be' is among the English copula verbs that is most problematic to an Indonesian learner of English because of its multiplicity of forms and its non-existence in the Indonesian language.

\section{a. Omission of copula "be"}

The omission of the copula 'be' is one of the most common errors committed by many Indonesian learners when writing in English. From the data, it is discernible that many learners tend to leave out altogether the copula 'be' in their writing as exemplified in Table 12.

Table 12 Omission of copula 'be'

\begin{tabular}{|c|c|}
\hline $\begin{array}{r}\text { Erroneous Form } \\
\end{array}$ & Correct Form \\
\hline I a student & I am a student \\
\hline Indonesian: Saya adalah seorang siswa & \\
\hline She a housewife & She is a housewife \\
\hline Indonesian: Dia ibu rumah tangga & \\
\hline *He an English teacher & $\mathrm{He}$ is an English teacher \\
\hline $\begin{array}{l}\text { Indonesian: Dia seorang guru bahasa } \\
\text { Inggris }\end{array}$ & \\
\hline *My uncle a merchant & My uncle is a merchant \\
\hline $\begin{array}{l}\text { Indonesian: Paman saya seorang } \\
\text { pedagang }\end{array}$ & \\
\hline My sister also a student & My sister is also a student \\
\hline $\begin{array}{l}\text { Indonesian: Saudara (pr) saya juga } \\
\text { seorang pelajar }\end{array}$ & \\
\hline
\end{tabular}

It is not surprising that this phenomenon happens because the presence of the copula 'be' is most of the time not essential in a Indonesian sentence.

\section{b. Wrong form of copula 'be'}

Another reason for the occurring errors is the fact that the copula 'be' has more distinct forms with respect to person, number, and tense than any other verb in English. The verb 'be' has three distinct present tense and two past tense forms as illustrated in Figure 1 below: 


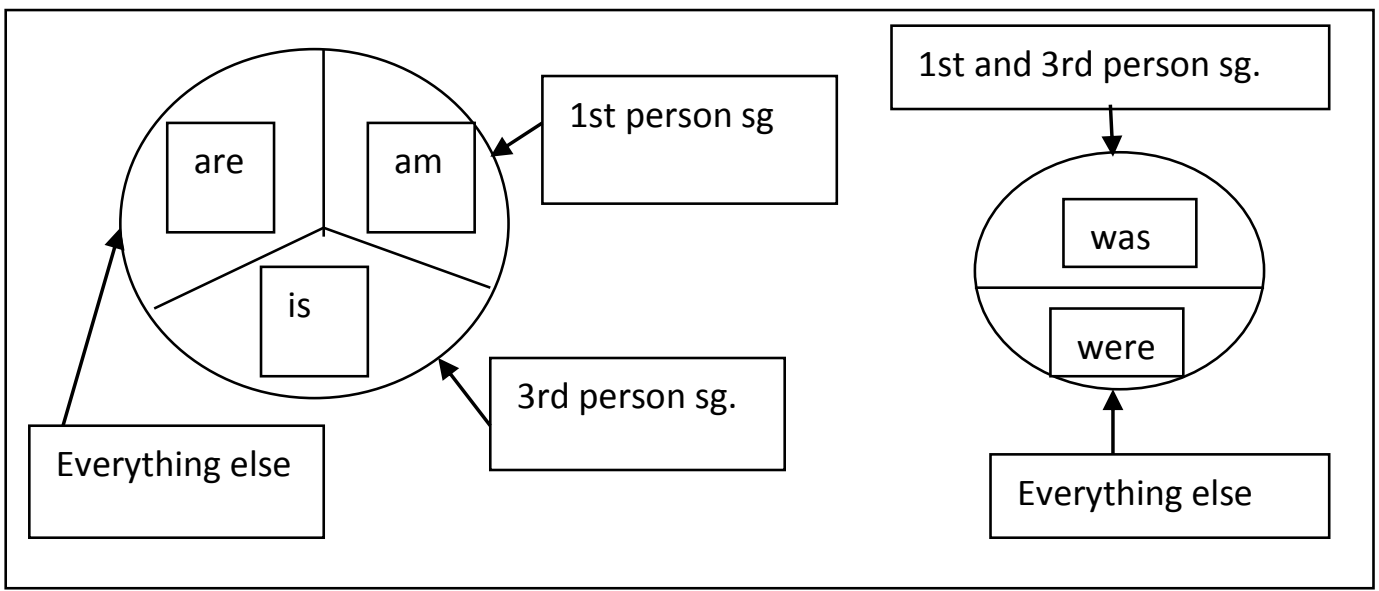

Celce Murcia, (1999:54)

The existence of the varied forms of below: the copula 'be' in English which have multiple parallel forms in Indonesian could 1) use present tense form of 'be' for the past tense form and vice versa:

Table 13 Errors in the use of tense

\begin{tabular}{ll}
\hline \multicolumn{1}{c}{ Erroneous Form } & \multicolumn{1}{c}{ Correct Form } \\
*My mother are beautiful and kind & My mother is beautiful and kind \\
Indonesian: Ibu saya cantik dan baik & \\
hati & Last month, my father was in Bali \\
*Last month, my father is in Bali & \\
Indonesian: Bulan lalu, ayahku ada di & \\
Bali & He is in the garage now \\
"He was in the garage now & We $\underline{\text { are very happy family }}$ \\
Indonesian: Dia sekarang ada di garasi & \\
*We were very happy family & \\
$\begin{array}{l}\text { Indonesian: Kami adalah keluarga } \\
\text { bahagia }\end{array}$ &
\end{tabular}

2) use the plural form for the singular form (Table 14) and vice versa:

Table 15 Errors in the use of plural and singular form

\begin{tabular}{|c|c|}
\hline Erroneous Form & Correct Form \\
\hline $\begin{array}{l}\text { "My mother's hobbies is cooking, } \\
\text { reading, and watching TV }\end{array}$ & $\begin{array}{l}\text { My mother's hobbies are cooking, } \\
\text { reading, and watching TV }\end{array}$ \\
\hline $\begin{array}{l}\text { Indonesian: Hobi ibu saya adalah } \\
\text { memasak, membaca, dan menonton TV }\end{array}$ & \\
\hline $\begin{array}{l}\text { *My family and I am very happy } \\
\text { Indonesian: Saya dan keluarga sangat } \\
\text { bahagia }\end{array}$ & My family and I are very happy \\
\hline
\end{tabular}


The forms of copula 'be' in Indonesian and English are a case of divergent phenomena where one form in Indonesian appears in many forms in English. Given the complexity of the forms that the copula 'be' can appear in English, learners sometimes tend to use the incorrect forms in place of the correct ones.

\section{Conclusion}

Where this study is concerned, out of 315 occurrences of determiners found in the students' essays, a total of $63(20 \%)$ were incorrectly used. On the other hand, out of 213 instances of usage of SVA, 85 (40\%) were erroneous, while out of the total of 324 usage of copula 'be', 97 (30\%) were wrongly produced. This study also shows that omission and wrong forms used are the two most common types of errors in all three grammatical categories.

Although not all errors are due to mother tongue interference, a large number of errors identified in the use of determiners, subject verb agreement, and copula 'be' reflected the interference of the Indonesian grammar. Thus, the problems of acquiring EFL in MTs Darul Ulum Sukosewu can still be largely due to mother tongue interference. Therefore remedial measures should be taken to implement approaches that could best assist students in these problematic areas. This study has identified a number of errors that seem to be attributable to the interference of L1. It is imperative then to implement measures to minimize the chances of occurrence of these errors by looking into the development of teaching materials and that of teaching practices within and outside the classrooms.

\section{References}

Abdullah Hassan. 1993. Tatabahasa pedagogi Bahasa Melayu. Kuala Lumpur: Utusan Publications and Distributors Sdn. Bhd.

Celce-Murcia, M. \& Larsen-Freeman, D. 1999. The grammar book - an ESL/EFL teacher's course. Rowley: Newbury House.

Hazita Azman. 2006. English Literacy Education in Rural Malaysia. In Shanta Nair- Venugopal et al. (eds.). Writing the past into the present, pg 272-280. Bangi: Penerbit UKM.

Nooreiny Maarof. et.al. 2003. Keupayaan penguasaan kemahiran Bahasa Inggris di kalangan pelajar Melayu dalam arus globalisasi. Dlm. Prosiding Seminar Kebangsaan Arus Perdana 11, hlm, 226-266. Bangi: UKM.

Norrish, J. 1992. Language learners and their errors. London: Macmillan Publishers. Shaari Awaluddin. 1987. The use of tenses in the written English of the Secondary Three students in Malaysia. Singapore: SEAMEO Regional Language Center. 